\title{
Health management of beef cattle: A case study
}

\author{
Tyagita Hartady*1,2), Rini Widyastuti ${ }^{1,3)}$ and Andi Hiroyuki ${ }^{1,2)}$ \\ ${ }^{1)}$ Study Program of Veterinary Medicine \\ ${ }^{2)}$ Department of Biomedical Sciences, Faculty of Medicine \\ ${ }^{3)}$ Laboratory of Animal Reproduction and Artificial Insemination, Faculty of Animal \\ Husbandry \\ Universitas Padjadjaran \\ J1. Raya Bandung Sumedang No.KM 21, Hegarmanah, Kec. Jatinangor, Kabupaten \\ Sumedang, Jawa Barat 45363. Indonesia.
}

Submitted: 19 April 2020, Accepted: 03 June 2021

\begin{abstract}
The reports about how are farmers able to prevent, identify and treat the animal diseases to not get worse while the production is still maintained, are limited. The application of the standard good farming practices is also not well documented. Therefore, to provide adequate information about beef cattle health management in smallholders, especially in Indonesia; this study was conducted at "Putra Nusa " Beef Cattle Group, located in Kalensari Hamlet, Kondangjajar Village, Cijulang District, Pangandaran Regency. The study was carried out by survey and observation to determine the farmers' level of knowledge about health, care and treatment of beef cattle. The result showed that farmers do not have a background in animal health, resulting in a lack of knowledge about beef cattle health management. Most breeders rely on natural ingredients to treat sick animals. Farmer's concern about vaccination and routine anthelmintic administration was only about $15 \%$ and $22 \%$, respectively, contributed to the increase of helminthiasis cases (45\%). Improve the knowledge about cattle diseases supported by the easy access to veterinarian will minimize the losses of breeders.
\end{abstract}

Keywords: Beef cattle; Farmer; Beef cattle diseases; Beef cattle health; Beef cattle management

\footnotetext{
*Corresponding Author: tyagita@unpad.ac.id
} 


\section{INTRODUCTION}

Being a good standard farm, either farmer and stockmen acquired to know how to prevent, control and treat animal diseases. A farmer should apply a farm hygiene trough biosecurity practice and minimize the transmission of infectious diseases. When the animal sick, farmers or stockmen should notice and soon apply some treatment correctly. Alternatively contact the nearest veterinarian to help the problem solved without hesitation. The Indonesian government has regulated Animal Husbandry and Animal Health related to animal care, veterinary medicine, animal health services, animal disease control and prevention, disease rejection, reproductive medicine, conservation medicine, veterinary medicine and animal health equipment, and food safety in the Regulation Number 18 of 2009 (Direktorat Jenderal Peternakan dan Kesehatan Hewan, 2009).

The care of sick animals must be in accordance with the rules set by the authority until the animals get cured, as well as a decrease in production before death can be avoided. Through training or seminars from the experts, farmers can gain knowledge and experience in understanding how to properly treat animal diseases. The hope is that no party will be scathed, such as ineffective medicines, mistakes in administering drugs that increase costs and endanger animal safety, reduce animal production, or even economic losses due to animals' death.

In Indonesia, there are still many problems faced by farmers in applying standard good farming practices. The majority of problems that exist are the lack of knowledge about the principle of raising livestock which includes; lack of proper feed and feed factor support, poor business knowledge and management, poor access to information and markets, high incidence of livestock disease and mortality. However, this problem is also related to higher policy concepts, such as; ineffective institutional and policy capacity. Furthermore, the study of innovation and technology transfer is weak also processed products and markets have not yet developed (Rischkowsky, 2017). However, it is not fully understood about how are farmers able to prevent, identify and treat the animal diseases to not get worse while the production is still maintained. The application of a good standard farming practices is also not well documented up to know. Therefore, the aim of the study was to provide adequate information about beef cattle health management on smallholder farms, especially in Indonesia.

\section{MATERIALS AND METHODS}

The "Putra Nusa" Beef Cattle Group is located in Kalensari Hamlet, Kondangjajar Village, Cijulang District, Pangandaran Regency. The group consisted of 27 members and 61 beef cattle with types including: Ongole (PO) breeds, Simental Limousine and Pasundan cattle. The feed contained fresh forage, given in the morning and evening. Water supply was always under breeders' controlled. The study was carried out by survey and observation to determine the farmers' level of knowledge about health, care and treatment of beef cattle.

\section{RESULT AND DISCUSSION}

From the observation in the field, some information were gained from the farmers' background. The majority of farmers are male in productive age, range of 17 to 59 years old dominantly graduated from senior high school. The average farmer has been focusing on animal husbandry for 6-10 years with varying ownership methods, private asset and profit sharing (Table 1). 
Table 1. General background of Putra Nusa farmers

\section{Parameter}

Percentage (\%)

Age (years old)

$17-59$

$>60$

Education

Elementary school

Junior high school

Senior high school

Gender

Male

Female

Ownership

Private asset

Profit sharing

Duration of farming (years)

$1-5$

$6-10$

60

$>10$

25

Observation in the beef cattle, showed that most of the beef cattle were suffering from helminthiasis (45\%), subsequent with diarrhoea $(30 \%)$ and bloat $(25 \%)$ with the most common symptoms are fever, loss of appetite and paralyzed for about 3 days (Fig. $1)$.

When the animals were sick, the local farmers rarely consult to the veterinarian immediately to treat their beef cattle. Initially, most farmers will make traditional ingredients, continued with administered human commercial medicine from the nearest stalls. Just when the animal does not improve, then the farmer will contact the nearby veterinarian and will be served after queueing.

Unfortunately, the steps of treatment they have taken have not been supported by adequate knowledge of the drugs and their proper administration, also the right handling technique of beef cattle. Thus, the medicine wasted and have a bad impact on healing animals (Fig. 2).

\section{A. Diseases observed in the beef cattle}

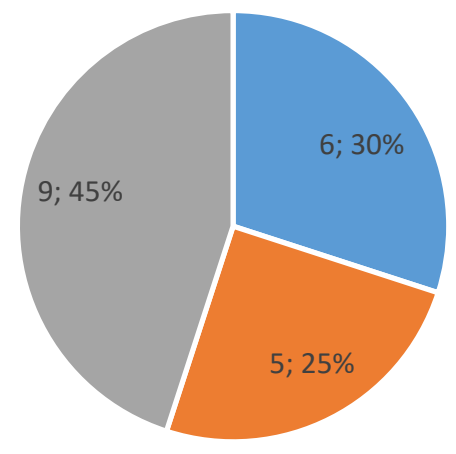

- Diarhea Bloat Worm infestation 
1.B. Clinical signs observation

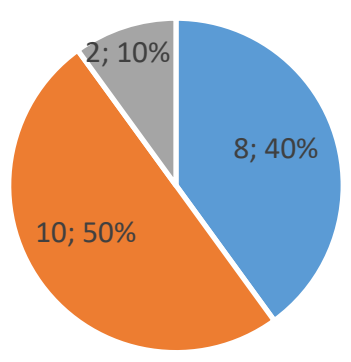

- Inappetance $\quad$ Fever $\quad$ Paralysed for 3 days

Figure 1. Cases of disease that are frequently found on farms (A) Common symptoms of the disease that are often found by farmers (B)

2.A. Efforts to cure sick beef cattle

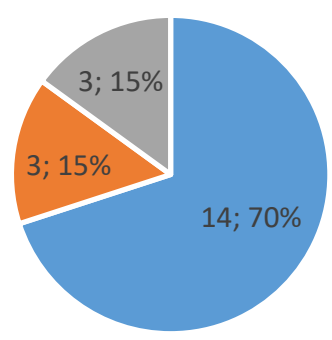

- Traditional formula as first aid $=$ Consult to the vet

- Human commercial medicine

\section{B. Difficulties in treating sick beef}

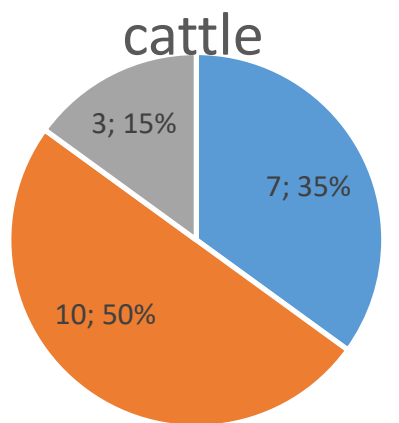

- Limimted knowledge of beef cattle diseases

- The vets were unreachable

- Drugs administration were challenging

Figure 2. The first action taken by the farmer if the cow is sick (A), Obstacles experienced by the farmer when the cow is sick (B) 
The farmers believed that tamarind is the best natural ingredient to solve the health problem of their beef cattle. The farmers also used coconut water and Sembung leaves (Blumea balsamifera), palm sugar, anthelmintic, vitamin, coconut oil and
Cebreng leaves (Gliricidia sepium). Some medications were commercially provided by the local paramedics (55\%), Goverment officer of Animals Husbandry (25\%), nearby stall $(10 \%)$ and the rest are from unknown source (Fig. 3).

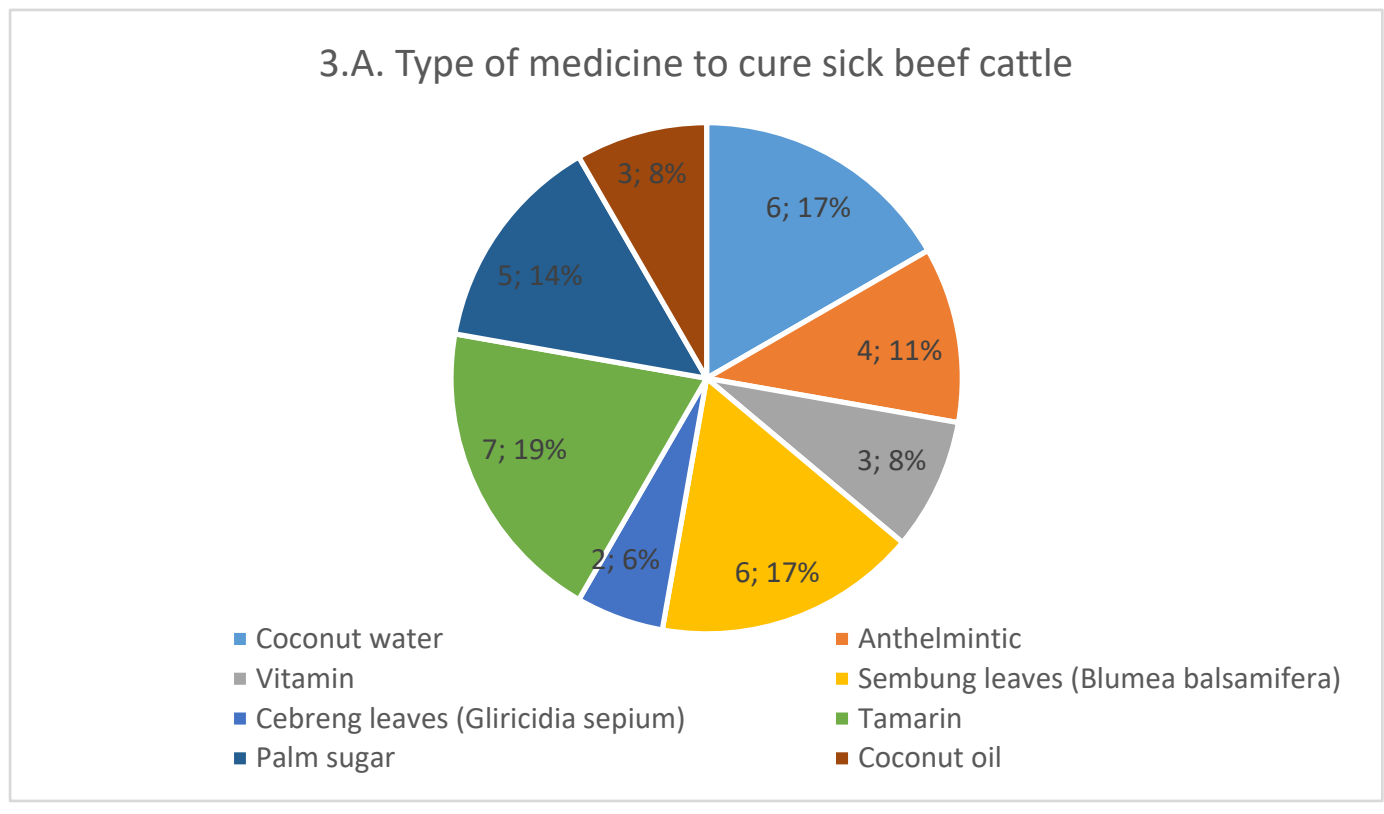

3.B. Source to reach the drugs for the sick beef cattle

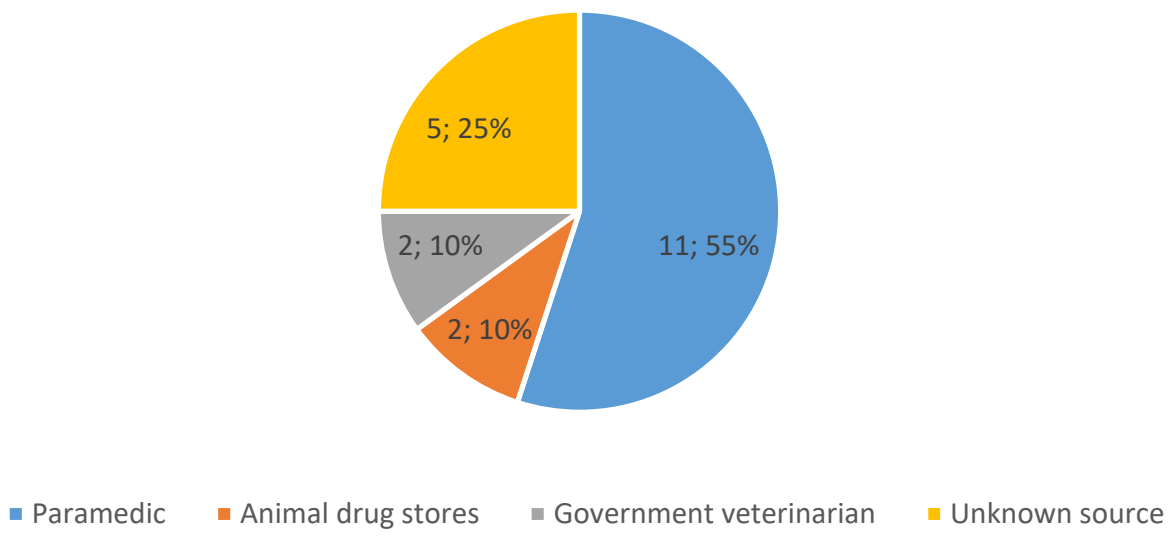

Figure 3. (A). Type of treatment given as first aid (B). The place to get the medicine given for first aid.

Traditional ingredients are practically found in nature and are relatively inexpensive that can be immediately given to the sick animals and are effective as first aid. Knowledge of the efficacy of natural ingredients is obtained from generation to generation. Indonesian farmers believe that mixture of tamarind and palm sugar is very effective in overcoming loss of appetite to treat indigestion (Herliyanto, 2018). Coconut water is very useful to restore energy, lower blood pressure, reduce the risk of cardiovascular disease, relieve stress and stiff muscles (Jamaluddin, 2018). Coconut water has many nutritional contents, as in $100 \mathrm{~g}$ coconut water has water content 
$(94,180 \mathrm{~g})$, protein $(0.120 \mathrm{~g})$, lipids $(0.073$ g) and sugar $(5.230 \mathrm{~g})$. Coconut water also contains ions of calcium, iron, magnesium, phosphorus, potassium, sodium, $\mathrm{Zn}, \mathrm{Cu}$ and Mn. Various vitamins including A, D, E, K, B1, B2, B3, B5, B6, B12, C, folate, choline, betaine and amino acids are highly found in young coconut water. While Sembung leaves were believed as anti-diarrhoea, gain appetite and reduce fever since it is rich of borneol, cineole, limonene, dimethyl ether chloroacetophenone (Pemerintah Kota Medan, 2015). Bloat in ruminant is potentially reduced by coconut oil and it has been used for decades. Farmers administer the $250 \mathrm{ml}$ coconut oil orally to remove the gas out from the rumen (Cybext, 2019). Cebreng leaves (Gliricidia sepium) is a high protein source diet that is digestible for ruminant. They increased microbial activity by providing an improved ecosystem in the rumen, so the digestion rate of the fibrous basal diet increased. When tannins are present in moderate amounts, part of the leaf's protein may pass out the rumen fermentation and supply amino acids directly to the intestine (Preston, 1992).

The concerns of farmers to prevent worms from occurring in their cows are relatively low. This can be seen from the data obtained which shows that around $45 \%$ of worm cases are found in the field and only $11 \%$ of farmers carry out anthelmintic administration. Most farmers are still reluctant to provide anthelmintic regularly to these animals. They doubt the statement that many worm eggs are attached to the grass or hay of cattle feed, and when developing into worms will reduce the nutrition consumed by the cows (Saryono, 2018). Service from veterinarians in the field is quite arduous. As a result, farmers prefer to consult their cattle health problems to the paramedics as they are more approachable. However, paramedics are allowed to provide treatment except surgery.

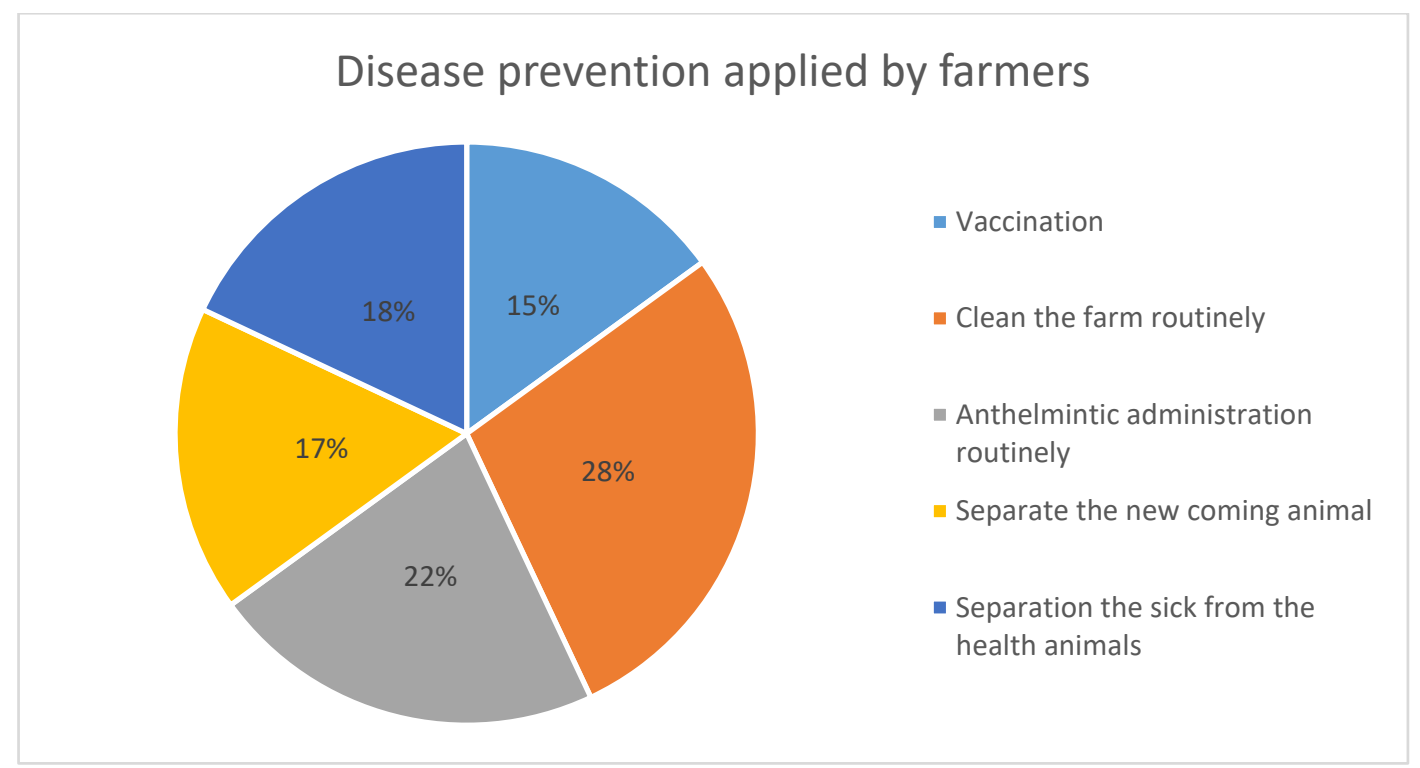

Figure 4. Actions taken by farmers to prevent diseas

So far, farmers have tried their best to ensure the health of their animals. Cleaning the cage regularly is the easiest thing for farmers to implement (Fig. 4). Although not many farmers routinely administer anthelmintic, they know that it is an effort to prevent worms. To prevent disease transmission, sick cows are separated from healthy cows. Separation was also carried out on the new cage dwellers. The last most important thing is vaccination, but only $15 \%$ of farmers do it because the costs are too high for others. Other reason is because breeders, especially fattening, do not want to because the nourishment period is relatively short (Kusmargana, 2017). 


\section{CONCLUSIONS}

Based on the previous description of the beef cattle farms in Pangandaran, it would be preferable if the farmer improve the knowledge about beef cattle diseases supported by easiness in obtaining veterinary services until the beef cattle disease successfully reduced and the losses of breeders can be minimized.

\section{REFERENCES}

Cybext. (2019). Penanganan Kembung pada Ternak Sapi Secara Tradisional. http://cybex.pertanian.go.id/mobile/ar tikel/89757/PENANGANAN-

KEMBUNG-PADA-TERNAK-

\section{SAPI-SECARA-TRADISIONAL/}

Direktorat Jenderal Peternakan dan Kesehatan Hewan. (2019). Tentang Peternakan Dan Kesehatan Hewan Dengan Rahmat Tuhan Yang Maha Esa. In Undang-Undang Republik Indonesia Nomor 18. Presiden Republik Indonesia.

Herliyanto, W. (2018). Peternak Sapi dan
Kerbau di Sarolangun Resah. In Beri Air Gula Asam Jawa.

Jamaluddin, Z. A. (2018). Mengatasi Keracunan pada Ternak Ruminansia dengan Air Kelapa Muda dan Daun Bambu.

Kusmargana, J. H. (2017). Banyak Peternak di Bantul Enggan Memvaksin Ternaknya.

Machmüller, \& Kreuzer. (1998). in Milkman Grooming Co.

Pemerintah Kota Medan. (2015). Manfaat Daun Sembung untuk Obat Tradisional.

Preston, T. R. (1992). The role of multipurpose trees in integrated farming systems for the wet tropics.

Rischkowsky, B., Intano, F. T., \& Madarisa, F. (2018). The identification of problems affecting goat farmers' friendship forum in west sumatra province. Jurnal Peternakan Indonesia, 20(3), 181-192.

Saryono, S. (2018). Banyak Peternak Enggan Memberikan Obat Cacing. 